Cuadernos de Historia Moderna

ISSN: 0214-4018

http://dx.doi.org/10.5209/CHMO.63937

\title{
Bartolomé Bennassar in memoriam
}

Hace unos meses la Casa de Velázquez publicó el último libro de Bartolomé Bennassar Pérégrinations ibériques, esquisse d'ego-histoire. Es un magnífico libro donde se confía sin tapujos y sin grandilocuencia un humanista que presenta su visión de la historia y cómo ejercer el oficio de historiador. El texto termina con una página titulada "final de recorrido" como si el autor se preparase para la muerte que lo llevó consigo el 8 de noviembre pasado.

Quien fue catedrático de una única universidad, la de Toulouse, desde 1956 hasta 1990 y rector de la misma entre 1978 y 1980, ha realizado una obra inmensa casi totalmente dedicada a la historia del mundo ibérico. Sus libros desde su tesis Valladolid au siècle d'or publicado en 1967 hasta la Histoire de Madrid publicado en 2013 han hecho de él un profesor-investigador muy leído, muy escuchado, muy respetado. Un gran maestro.

Esta obra densa y fecunda es consecuencia de un talento excepcional, de un trabajo incesante y de una inmensa curiosidad. El talento se expresa particularmente en la calidad de la escritura que lo condujo a componer novelas. Varias han tenido un gran éxito, por ejemplo Le baptême de la mort, que ha sido llevada al cine, o Toutes les Colombies, que ha sido traducida al español. Escritor nato, Bartolomé Bennassar ha publicado siempre obras de pluma clara y elegante. La lectura del Homme espagnol (1975), de la Inquisition espagnole (1979), del Voyage en Espagne (1998), escrito con Lucile su esposa, o la de sus biografías Juan de Austria (2000), Cortés (2001) o Velázquez (2010) es muy amena. Lo son también las diversas síntesis a menudo redactadas con otros autores - ejercicio que confesó gustarle mucho- desde el famoso manual sobre el siglo XVI (1972) escrito en colaboración con Jean Jacquart hasta la Histoire du Brésil (2000) escrita en colaboración con Richard Marin. Estas síntesis son el resultado del dominio de una vasta bibliografía a partir de la cual Bartolomé Bennassar suele abrir caminos.

Otro elemento fundamental de su práctica historiadora es un profundo conocimiento de los espacios que está estudiando. No es un azar que titulase su libro de ego-historia Pérégrinations ibériques. Conocía bien, por supuesto, toda España, pero a lo largo de su vida él, cuya formación primera era la de geógrafo, emprendió viajes para ver y entender paisajes, monumentos, modos de vida del Norte de África a América. Conservo las notas del viaje que hizo en 1997, desde Colombia a Bolivia, para preparar las páginas de un capítulo del libro Le temps de l'Espagne (1999).

Su curiosidad y su afán de comprender los hechos más complejos guiaron a este hijo de un mallorquín emigrado a Francia hacia el estudio de la España del siglo XX. Sus dos libros sobre la Guerra Civil (2005) y sobre Franco (1995) y los capítulos de la Histoire des Espagnols (1985) dedicados al siglos XX han estado marcados por la búsqueda de un difícil equilibrio que a veces no ha sido entendido. Había ocurrido 
lo mismo con el libro sobre la Inquisición que recibió críticas por no insistir sobre la tremenda represión del tribunal. Pero los críticos no se daban cuenta de que él ponía el acento sobre un resorte sutil y fundamental de la política inquisitorial, lo que llamó la pedagogía del temor, feliz formula que finalmente ha dejado huella.

El campo de investigación de Bartolomé Bennassar es singularmente amplio. Cronológicamente ha prestado atención a todos los siglos desde el XVI hasta el XX. Especialmente mantuvo el objetivo constante de abarcar todos los territorios de las monarquías ibéricas para mejor analizar el funcionamiento de estas construcciones complejas y duraderas. En esta vía, hablaba de la dimensión universal de España. Temáticamente ha pasado con igual suerte de la historia económica a la historia política, de la historia social a la historia cultural, siendo por ejemplo uno de los pioneros de lo que hemos llamado, algún tiempo, la historia de las mentalidades.

Y metodológicamente. El libro Les chrétiens d'Allah (1989), escrito con Lucile, es un excelente ejemplo de su oficio de historiador. En la base está una impresionante investigación archivística de Las Palmas a Palermo, de Lisboa a Venecia. Luego reúne el estudio de seis trayectorias significativas - cada una verdadera obra literaria- y el examen minucioso de una base de datos de 1.500 casos. Lejos de cualquier moda, demostrando como la historia serial y la historia de casos no eran irreconciliables, Bartolomé Bennassar construyó, con total libertad, una magna obra destinada a dar placer a los lectores, a suscitar reflexiones y a provocar vocaciones.

Bernard Vincent

École des Hautes Études en Sciences Sociales, París 